\title{
Mood, Method and Affect: Current Shifts in Feminist Theory
}

\author{
Ellen Mortensen ${ }^{1 *}$
}

Published: October 30, 2017

\begin{abstract}
Epistemic habits in feminist research are constantly changing in scope and emphasis. One of the most striking ruptures that we can observe these days, at least in the humanities, is a renewed epistemic interest among feminists in the question of mood, where both positive and negative affects come into play. Mood figures in a number of theoretical traditions, ranging from the hermeneutics of Heidegger, Gadamer and Ricoeur, as well as in phenomenology, psychoanalytic theories of affect and in Deleuzian affect theory. In the article I want to explore two different approaches to the question of mood in feminist theory. In the first part, I will investigate Rita Felski's treatment of mood in her recent attack on 'critique' as well as in her proposed alternative, her 'post-critical' approach to reading and interpretation. In so doing, I will formulate some questions that have emerged in my attempt to grapple with Felski's post-critical approach. In the second part of this essay, I will delve into another understanding of the concept of mood, namely Deleuzian affect, and more specifically, as it has been embraced by feminist theorists such as Rosi Braidotti and Elizabeth Grosz in their respective theoretical works. In the concluding part of this article, I will discuss some of the implications of the different takes on mood for feminist epistemic habits.
\end{abstract}

Keywords: feminist theory, mood, method, Deleuzian affect

\section{The Malaise of Critique}

According to Rita Felski, we are witnessing a sea change in the way in which feminists approach the act of reading and interpretation, not only when it comes to the question of mood, but by implication, our understanding of method. In her paper, 'Identification: A Defense' (2016), Felski presents a bold line of argument, defending positive identification and affective attachment as a valid approach in reading and perceiving works of art. Her intervention is furthermore elaborated in her polemic book, The Limits of Critique (2015), where she attacks critique, while undertaking a detailed scrutiny of current interpretive practices of critique-which she claims has attained a hegemonic position in literary and cultural studies over the course of the last four decades.

Felski (2015: 1) challenges critique's claim to legitimacy and superiority based on an ethos of reading that demands negative affects, such as ironic detachment, disenchantment and the use of highly sophisticated strong theory; in short, a mood and method that embraces a hermeneutics of suspicion.' In addition, she casts doubt over critique's premise that these reading practices of soupcon are inherently more radical and subversive when it comes to the capacity to effect political and social changes, than other reading approaches do. According to Felski, the state of affairs is quite the contrary: critique constitutes today an 'anti-normative normativity' in feminist cultural studies, where most actors in the institutions are expected to perform readings in the mood of negativity, using methods of scrutiny that claim to unbind, unravel, demystify, de-familiarize, deconstruct and unveil oppressive power structures or regimes. Critique has, in Felski's assessment, become the dominant mood and method in these research fields today, and one would be hard put, she says, to argue that the critical style of thought represents a challenge to the institutions of power/knowledge today.

Rita Felski presents an unabashed defense of positive identification and calls for the re-valuation of positive affect of attachment in the aesthetic experience, which she posits as an antidote to the negative and melancholy mood at work in critique. Contrary to critique's skepticism and symptomatic reading strategy, Felski opts for an up-front and close-up scrutiny and a 'thick' description. She starts off with an examination of critique's use of 
rhetoric and form, affect and argument. She concludes that, as a distinct mode of interpretation, critique revels in dis-enchantment and ironic distance; it favours the archeological method, which requires that the critic 'delves deep' and 'stands back,' while mistrusting the text's surface level in order to wrestle from the text that which it allegedly attempts to withhold from its readers. Hence, Felski is able to identify, through her descriptive approach, what turns out to be 'a quite stable repertoire of stories, similies, tropes, verbal gambits and rhetorical ploys' (Felski 2015: 7).

Critique is thus approached as a genre and an ethos, and Felski regroups a vast range of interpretive strategies within this particular style of thought: symptomatic reading in general, be it Marxist ideology critique, psychoanalysis, deconstruction, Foucault's historicism, or any other reading approach which scans texts for signs of transgression or resistance; in short, every school of thought that has been embraced by feminists during the last three decades. Felski also includes what she calls a practice that she identifies as 'critique of critique,' referring to recent texts, such as Robyn Weigman and Elizabeth Wilson's essay on 'anti-normativity's queer conventions' (Felski 2015: 146).

Despite using a broad brush in her attempt to conjure up a picture of critique, Felski by and large gives a persuasive account of the practices of critique. She thus succeeds in showing not only the main characteristics in mood and method of critique, but in addition, that it is only one style of thought used in literary and cultural studies among many others, irrespective of its own attempt to appear as all-encompassing and without limit. Felski convincingly reveals that - contrary to its own ethos of impersonality, detachment and distance - critique has its own distinct affects, even if these are for the most part steeped in a negative mood of disenchantment, mistrust, melancholy and gloom. She is overtly skeptical towards critique's inflated belief in and claims to being inherently progressive or emancipatory, and she has grown weary of critical thought's claim to inherent radicalism. Likewise, she is critical of the inability of certain actors to acknowledge how feminist academics engaging in critique are implicated - and may well serve as complicit actors - in the workings of contemporary capitalism, both within and outside the academic institutions.

\section{Felski's Post-Critical Approach}

While aiming at challenging the hegemonic position of critique, Felski also proposes a distinct alternative to this style of thought. In so doing, she makes a concerted effort not to revert to critique herself in her own treatment of critique. Instead, she makes use of the phenomenological method of 'thick' description of critique as a distinct interpretive strategy. In part, she bases her account of critique on Eve Kosofsky Sedgwick's early intervention, 'Paranoid Reading and Reparative Reading' (Sedgwick 1997), where Sedgwick takes issue with the claims and mood of critique in an attack that was primarily aimed at Judith Butler. Sedgwick lists five characteristic traits of critique and labels them an instance of 'paranoid reading.' Felski both reiterates and elaborates these prominent traits ${ }^{1}$ in her own five-point description of critique in her book, where she lays out its rhetoric of 'standing back' and 'digging deep': 1. Critique is secondary 2. Critique is negative 3. Critique is intellectual 4. Critique comes from below 5. Critique does not tolerate rivals (Felski 2015: 121-150).

As an alternative, Felski calls for a reorientation and a re-description of the critical practices associated with the 'hermeneutics of suspicion,' in accordance with Paul Ricoeur's understanding when he coined the term, hailing Nietzsche, Freud and Marx as initiators of a new mode of interpretation (Ricoeur 1970). But according to Felski, Ricoeur paid close attention to the question of mood or attunement and insisted on the need to adopt a wide range of methodologies in the interpretation of works of art. Thus, in addition to a 'hermeneutics of suspicion,' he also called for a 'hermeneutics of trust or restoration.' This attention to diversity in moods and methods was not adopted or sanctioned by the feminist practitioners of critique, who according to Felski gave priority to disenchantment and suspicion (Felski 2015: 30-39).

Her approach to the study of literature is a set of reading practices, which draw on a number of different philosophical and theoretical traditions and movements. While arguing for a need for a reorientation and a redescription of what actually happens in critical reading practices, Felski wants to move away from negative aesthetics and instead orients herself towards what she calls relational ontologies. ${ }^{2}$ In this move, she merges diverse,

\footnotetext{
${ }^{1}$ Sedgwick's five points of paranoid reading are: 1) anticipatory; 2) reflexive and mimetic. 3) strong theory 4) a theory of negative affects 5) it places its faith in exposure (Sedgwick 2003, 130).

${ }^{2}$ By relational ontologies, Felski invokes Bruno Latour and his Actor-Network-Theory of ontological relations, which she formulates as follows: For Latour, by contrast, there is no historical box and no society, if we mean by this term a bounded totality governed by a predetermined set of structures and functions. Society does not stand behind and steer human practices, as if it were outside of and ontologically distinct from these practices, akin to a shadowy, all-seeing, puppet master. Rather, what Latour calls the social is just the act and the fact of association, the coming together of phenomena to create assemblages, affinities and networks (Felski 2015: 157).
} 
and one might suggest, perhaps incompatible human and non-human actors and practices. She coins a hybridity that she names a 'post-critical' approach, where we discern the following preferential attachments discussed below.

The first attachment that Felski makes in sketching out an alternative to critique is to the tradition of philosophical hermeneutics that pays heed to the notion of 'mood' as the tacit foundation of all interpretive acts. In her book (2015: 20), she makes an explicit reference to Martin Heidegger's thinking on 'Being-in-the-world' as 'Being-with,' notably as a mode of attunement, Stimmung (Heidegger 1962). In addition, Felski wants to retrieve that which the practitioners of critique have forgotten or overlooked in their appropriation of Paul Ricoeur's understanding of a 'hermeneutics of suspicion,' namely a 'hermeneutics of trust or of restoration' (Felski 2015: 32), which speaks of the more positive affects involved in the act of interpretation.

The second theoretical attachment that Felski establishes is to phenomenology, which among others attempts to establish the parameters of a first person, subject position. She distances herself from the Husserlian notion of radical reduction to a 'transcendental ego' (Husserl 2006), which is thought of as a disembodied entity, and prefers instead the casting of the first person as an embodied subject position, as it is formulated in the phenomenological and existential philosophy of Simone de Beauvoir (Beauvoir 1997) and later elaborated by Toril Moi (2001). According to Moi, Beauvoir's notion of existential situation is both a dimension of facticity and of freedom, projected onto the future, and can therefore never be reduced to a fixed essence or identity (2001: 65-66). Felski aligns herself with Moi's reading of Beauvoir, and understands the first person position as an embodied situation; one that accounts for the idiosyncratic, embodied style of the subject and for the sociality inherent in the horizon in which the situated subject dwells. Felski's call for a return to phenomenology and Moi's appropriation of Simone de Beauvoir is partly supplemented by other theorists, such as Chantal Mouffe, Marielle Macé and Yves Citton, who embrace aspects of pragmatism and ordinary life philosophy in order to formulate a positive theory of subjective reading that is grounded in lived existence and in embodied affects.

Felski also advocates for reviving the 'thick' descriptions that the method and practice of phenomenology provides when she calls for a more thorough and complex description of the phenomena of identification and attachment in reading practices. She supplements this phenomenological description with insights that the film critic Murray Smith (Smith 1995) introduced in his treatment of identification in film theory. Murray argues that the term identification ought to be divided into four different issues and experiences, namely alignment, allegiance, recognition and empathy. According to Felski, these four aspects are 'analytically and experientially distinct, though they can of course be combined' (Felski 2015: 8).

A third positive attachment that Felski makes in her delineation of an alternative to critique is to the work of Sedgwick, who introduced not only queer theory (together with figures such as Teresa de Lauretis and Judith Butler), but also the importance of affect in the act of reading literature. Sedgwick launched the notion of 'reparative' as opposed to 'paranoid' reading, terms that she retrieved from Melanie Klein (Klein 1998) and which she marshalled as an alternative to critique's symptomatic reading practices. Felski repeatedly refers to Sedgwick's contribution and values her emphasis on affect; she thus aligns herself with Sedgwick as well as queer theorists like Heather Love and Elizabeth Weed, who both welcome the inclusion of affect in interpretive practices. These queer theorists, as opposed to for example Judith Butler (Butler 1990), attest to the fact that not every scholar engaged in queer theory categorically embraces the mood of negativity, disenchantment and soupcon, but also love and joyful attachment. Accordingly, Felski includes them in her group of allies, in opposition to queer theorists such as Butler, Weigman and Wilson.

Felski's fourth attachment in fleshing out her 'post-critical' approach to literary and cultural studies is to the work of Bruno Latour and his Actor-Network-Theory, or ANT (Latour 2005). ANT alludes to the intricate network active in the ant hill, where every ant engages in a complex network connected to other ants, forming a special kind of sociality. Felski's interest in Latour is in part motivated by the fact that his network theory allows her to detect how critique as an ethos of reading is based on shared habits of thinking and established idioms. Hence, critique has succeeded in the building of an intellectual community and in establishing its own network of attachments, which has attained a hegemonic position in academe, especially in the U.S.

Furthermore, Latour's Actor-Network-Theory allows Felski to elaborate her own thinking on the practice of literary and cultural studies as a process that assembles a vast number of human and non-human actors, who through interaction and mutual negotiations form complex networks: 'scholars, computers, email-messages, journals, conferences syllabi; seminar rooms; monographs' (Felski 2015: 12). Felski agrees with Latour in that any kind of knowing is a 'mode of existence,' with its own 'vectors, orientations, chains of action and experience' (2015: 12). For her, reading literature is fundamentally a social enterprise, involving a complex network of actors, and can never be reduced to the reader-object dyad.

\section{Mood, Networks and Affect}

I find much of Felski's intervention both insightful and timely. That being said, I feel the need to question and challenge certain aspects of her proposed post-critical stance. First of all, I take issue with Felski's use of Heidegger 
and his ontological thinking on 'mood' as the basis for her re-thinking of affective identification. In Being and Time (Heidegger 1962), Heidegger carefully lays out, through his own version of a radical hermeneutics, the disclosure of Dasein's 'Being-in-the-world' as 'Being-with.' Heidegger's existential analytic is situated within his thinking on the hermeneutic circle, as the horizon into which we are all thrown, together with other beings. Dasein as a 'BeingTowards-Death,' experiences its ownmost Being in authenticity and fundamental precariousness in the loss of self, which causes fear and angst. This mood, the Stimmung of fearfulness and angst, occurs when Dasein falls out of the category of 'das Mann,' that is, a falling out of the subject position in ordinary language. Heidegger's Stimmung, which reveals itself in its authenticity when cast in the negative, constitutes the ontological experience of a loss of ground, when Dasein is most attuned towards Being. Attunement or mood, according to Heidegger, occurs prior to and is constitutive of interpretation, which is always thought as secondary or derivative (1962:172-182).

Interpretation, as an act performed by the subject, happens in an ontic position, that is, in Dasein's experience of inauthenticity. Ontic interpretation is thus dependent on and derivative of Stimmung, thought as an ontological mode of Being. My question to Felski is therefore: How can identification, which she understands as an affective orientation in the positive, find its basis in Heidegger's thinking on mood, attunement or Stimmung? In, Stimmung as an authentic ontological experience is an event through which Dasein finds its ownmost Being in the loss of ground, one that is steeped in angst and negativity. Furthermore, it is Heidegger who - prior to Ricoeur's coining of a 'hermeneutics of suspicion' - was perhaps the practitioner par excellence of critique and who lays the ground for the later hermeneutic thinking on soupson, be it in Gadamer or Ricoeur. In his symptomatic readings of the history of philosophy (in part inspired by and in opposed to Nietzsche's thinking on interpretation), it suffices to refer to his work on the Pre-Socratics (Heidegger 1975) as well as to his work on Kant (Heidegger 1997), where Heidegger claims to unveil in his reading that which is silenced and hidden in Kant's thinking. In Felski's own words, this is the essence of what the practice of critique entails, namely to unveil that which the text presumably withholds.

I agree with Felski that Stimmung occurs prior to and constitutes the basis for interpretation, but in Felski's recasting of identification as an affective orientation of the first person towards its object, Stimmung becomes a positive affect that is lodged within the subject-object parameter of ordinary language, which for Heidegger is nothing but 'idle talk.' Such an appropriation is far removed from Heidegger's thinking on authentic attunement or Stimmung, which he understands as an ontological mode of existence, in attunement to the groundless ground of Being. When Felski translates Stimmung into a positive affect that secures the subject's affective attachment and identification to an object, it amounts to a misappropriation of Heidegger's thinking, and may serve as yet another instance of metaphysical, ontic appropriation of his ontological thinking.

My next point of contention with Felski pertains to her advocacy for Latour's Actor-Network-Theory (ANT), which she wants to import into the practices of literary and cultural studies. Latour's theory of the workings of complex networks - real or virtual - in contemporary Western societies is both relevant and useful. Like many other social theories that have been adopted by literary studies, I truly believe that an attempt to integrate some of Latour's methods at detecting and creating a cartography of networks at work in the reception and interpretation of literature - involving human as well as non-human, real and imaginary actors - could prove fruitful for literary studies. However, Felski remains quite vague as to how these studies should actually be conducted, and what methodologies should be used. Her accounts of the salience of ANT in both her paper and in her book are at best vague and underdeveloped. It remains unclear in Felski's account how this theory may function as a reading strategy and a mode of literary analysis in literary studies.

Felski's understanding of the aesthetic experience pertains on the one hand to the first person singular; this position is marked by the affective idiosyncrasies of the subject. But in addition, the subject is a product of sociality, i.e. fabricated and co-produced, involving an intricate network of actors. A valid question in this context is whether or not affective identification in the first person as it is understood in phenomenology can be merged with Latour's understanding of agency within the actor-network. In my assessment, Latour's notion of agency, which includes human as well as non-human entities, is far removed from Beauvoir's phenomenological, embodied notion of the subject, not to mention Heidegger's thinking on attunement in the ontological disclosure of Dasein. Felski herself seems to ignore any possible problems in lumping these various theories together to form a first person foundation for her alternative reading strategy of 'positive identification.' Can we just infer from this account that identification will function in the same way when applied to collectives or networks of human and non-human actors, and how is this solved methodologically? These critical questions aside, I commend her intervention into the problem of critique by way of mood and positive affective identification in feminist theory. Felski raises important methodological and theoretical questions pertaining to our epistemic habits, and her call for a redirection in literary studies is both valid and persuasive. 


\section{Deleuze and Guattari on Affect}

Even though Felski's intervention into the shortcomings of critique might be instructive and valid, there is another school of feminist thinking on affirmative affect that I find even more compelling, namely one which is nourished by Deleuze and Guattari and the philosophical legacy of Spinoza, Nietzsche and Bergson. Felski by and large overlooks this theoretical branch of thinking on mood. Symptomatically, I have found but one brief reference in her book to Deleuze and Guattari, in a subordinate sentence where she disclaims the two French philosophers and their attack on what they call 'intepretosis' (Felski 2015: 10). Unlike Felski, feminist theorists such as Rosi Braidotti and Elizabeth Grosz embrace Deleuzian philosophy, which takes a radically different view on affect. Neither Braidotti nor Grosz can be subsumed under Felski's rubric of critique in the negative mood, since they both emphasize affirmation and positive affects in their critical practices. Even though they read Deleuze and Guattari in different ways, both Braidotti and Grosz import the French philosophers' understanding of affect into their own feminist theories.

In Deleuze and Guattari's philosophy of life and becoming, they attempt to circumvent the idealist and rational philosophical tradition from Plato through Hegel. Thus, they seek - in part through the legacy of Spinoza, Nietzsche and Bergson - to produce ways of doing philosophy that values life; not as stable identity, but life in its becoming. According to Deleuze and Guattari, philosophy and art may serve life in as much as philosophy creates life-enhancing concepts and art produces affects. Affect is for them not a subjective emotion or a personal inclination, but connotes instead 'the incredible feeling of an unknown Nature,' and they write:

For the affect is not a personal feeling, nor is it a characteristic; it is the effectuation of power of the pack that throws the self into upheaval and makes it reel. Who has not known the violence of these animal sequences, which uproot one from humanity, if only for an instant, making one scrape at one's bread like a rodent or giving one the yellow eyes of the feline? A fearsome involution calling us toward unheard-of becomings. (Deleuze and Guattari 1987: 240).

For Deleuze and Guattari, when speaking of affect, it is a question of a capacity to act and to create movement, marked by different levels and qualities of intensity (of power), as opposed to a specific entity that is quantitatively measured through representational language, as in traditional metaphysics. Thus, affect in Deleuzian-Guattarian terms is (following Spinoza) above all 'the capacity to affect and to be affected' (Deleuze and Guattari 1987: 261):

To every relation of movement and rest, speed and slowness grouping together an infinity of parts, there corresponds a degree of power. To the relations composing, decomposing, or modifying an individual there correspond intensities that affect it, augmenting or diminishing its power to act: these intensities come from external parts or from the individual's own parts. Affects are becomings (Deleuze and Guattari 1987: 256).

In the process of 'becoming intense,' which marks a process of deterritorialization in different stages, Deleuze and Guattari include the notion of 'becoming-woman' as a first and necessary stage. They thus acknowledge that the molar identity of 'man' is being invested with oppressive power, notably through the patriarchal-capitalist assemblage. Molar, masculine identity must therefore be de-territorialized on the plane of organization in order for life forces to be liberated, allowing for affects to circulate freely, which again might allow new becomings on the plane of consistency or immanence.

Affects, as intensive forces, are crucial for the capacity to act in order to undermine the stability of molar identities and their oppressive assemblages. Deleuze and Guattari thus propose diverse strategies of deterritorialization in order to undo the existing patriarchal gender and sexuality regime, which serves the interest of man in capitalist societies. In their material ontology, 'becoming-woman' is the first stage, and one that all processes of deterritorialization have to pass through. They ask:

Why are there so many becomings of woman, but no becoming-man? First, because man is majoritarian
par excellence, whereas becomings are minoritarian. (...) Majority implies a state of domination, not the
reverse. (...) In this sense, women, children, but also animals, plants, and molecules, are minoritarian.
It is perhaps the special situation of women in relation to the man-standard that accounts for the fact
that becomings, being minoritarian, always pass through a becoming-woman (1987: 291).

Affects mobilize all further processes of deterritorialization, which start with 'becoming-woman' and move via 'becoming-animal,' 'becoming-molecular' and finally reach, 'becoming-imperceptible,' which constitutes the final stage of deterritorialization on the plane of consistency or immanence, from whence new becomings may spring 
forth. Deleuze and Guattari advocate in this context for a continuous dynamic self-production of multiple sexes and poly-sexualities in the war machine against the tyranny of the molar identities of patriarchal-capitalist assemblages.

Feminism, for Deleuze and Guattari, is an ideology of fixed gender and sexuality categories. As such, feminism is implicated in this power dynamic, and may attribute to solidify power within this oppressive state of affairs. Feminist critique may therefore function as reactionary and reactive forces in capitalist society. Furthermore, when Deleuze and Guattari propose ways of undermining patriarchal, molar power regimes on the plane of organization, they advocate for a dynamic self-production of multiple, un-natural, perverse assemblages, where the human body enters into productive relations with other affective entities, e.g. human, animal, machinic or artificial entities in order to create 'unheard-of becomings.'

Art and literature constitute 'blocks of affect' for Deleuze and Guattari, and in their view, artistic practices are intensive, i.e. affective processes of deterritorialization. Mimetic art and literature written in representational language are accordingly deemed inferior forms of artistic productions; only when art produces 'unheard-of becomings,' affects with a capacity to create new becomings, can art and literature be said to be successful. In What Is Pbilosophy, Deleuze and Guattari (1994) ponder the specific transformative function of literature as affect:

The affect goes beyond affections no less than the percepts goes beyond perceptions. The affect is not the passage from one lived state to another but man's nonhuman becoming. (...) [B]ecoming is an extreme contiguity within coupling of two sensations without resemblance or, on the contrary, in the distance of a light that captures both of them in a single reflection. André Dhotel knew how to place his characters in strange plant-becomings. Becoming tree or aster: this is not the transformation of one into the other, he says, but something passing from one to the other. This something can be specified only as sensation. It is a zone of indetermination, of indiscernibility, as if things, beasts and persons (...) endlessly reach that point that immediately precedes their natural differentiation. This is what is called an affect (1994:173).

Affect in Deleuze and Guattari is therefore not connected to a subjective feeling or a personal inclination, but is rather a sensation that involves not only a subjectivity, but an affective field that connects the subject's body with other living and non-living force-fields, thus involving forces of cosmic implications.

\section{Rosi Braidotti's Affirmative Feminist Critique}

In her thinking, be it on the 'nomadic' (Braidotti 1994), 'monstrosity' (1996), the 'ethics of affirmation' (2006) or 'the posthuman' (2013), Rosi Braidotti embraces Deleuze and Guattari and their thinking on affect. Throughout the last three decades, she has consistently argued for an affirmative approach to feminist inquiries and feminism's ethical responses to the challenges of our times:

This sort of turning of the tide of negativity is the transformative process of achieving freedom of understanding through the awareness of our limits, of our bondage. This results in the freedom to affirm one's essence as joy, through encounters and minglings with other bodies, entities, beings, and forces. Ethics means faithfulness to this potentia, or the desire to become. Deleuze defines the latter with reference to Bergson's concept of "duration," thus proposing the notion of the subject as an entity that lasts, that endures sustainable changes and trans-formation and enacts them around him/herself in a community or collectivity. Affirmative ethics rests on the idea of sustainability as a principle of containment and tolerable development of a subject's resources, understood environmentally, affectively and cognitively (2006: 246).

Braidotti's repeated attempts to circumvent the pitfalls of negativity in her theorizing is founded on an ardent commitment to affirmative practices, where she pays heed to embodiment, sexual and racial difference, multicultural and post-secular citizenship, issues linked to globalization, network societies, contemporary art and technoscience. In Metamorphoses, Braidotti accordingly argues that Deleuze might prove productive for feminist thinking because he 'takes the plunge into the ruins of representation and the sensibility of the post-human' (2002: 97), and she writes:

He wants us to confront the kaleidoscope of affects and desires that one is deliberately not socialized into becoming. As a consequence, Deleuze's nomadology is not only conceptually charged, but also culturally very rich. In as much as he invests creativity with nomadic force, Deleuze raises issues of sensibility, affectivity and ultimately, desire. It is on this field, therefore, that his encounter with feminist allies is the most resoundingly vocal (2002: 97). 
Braidotti here attests to the fact that Deleuzian affect forms an integral part of her own feminist theoretical project, which attempts to align his affective thinking with a host of other feminist thinkers, above all Irigaray and Haraway, in order to vitalize the field of feminist theory. She writes:

Deleuze redefines the practice of theory-making in terms of flows of affects, and the capacity to draw connections. Accordingly, Deleuze describes the subject as an affective or intensive entity and ideas as events, active states which open up unexpected possibilities of life. The truth of an idea, in other words, is in the kind of affects and the level of intensity that it releases. (...) Affectivity governs the truth-value of an idea. In juxtaposition with the linear, self-reflexive mode of thought that is favored by phallogocentrism, Deleuze defines this new style of thought as 'rhizomatic' or 'molecular.' These new figurations of the activity of thinking are chosen for their capacity to suggest web-like interactions and interconnectedness, as opposed to vertical distinctions. Deleuze defends this view of the subject as a flux of successive becomings by positing the notion of a 'minority' consciousness, of which the 'becoming-woman' is somehow emblematic (2002: 70).

In making active use of Deleuze and Guattari's notion of affect as a vital and creative force in feminist theorymaking, Braidotti usurps feminist theory's traditional reliance on rational and representational, reflexive models of thought. As such, Braidotti's understanding of affirmative affects differs radically from Felski's in that she does not approach the question of mood through the framework of phenomenology - such as an embodied individual subject or a social collective of agents - but rather as an ontological, collective flow or force at work in and through the subject or the collective. Furthermore, whereas Felski relies on a mimetic and a realist, descriptive mode of representation in her affective theorizing, Braidotti stresses the rhizomatic, deterritorializing, unpredictable and 'monstrous' couplings that may emerge in affective assemblages, effects of which by far exceed the control of the interpretative subject or its social network.

\section{Elizabeth Grosz: Art as Affect}

Another feminist theorist who finds great inspiration in Deleuze and Guattari's thinking on affect is Elizabeth Grosz. Throughout most of her work from the last thirty years, she delves into the thinking of Deleuze and Guattari and its relevance for feminist thought. Likewise, in her book Chaos, Territory, Art (Grosz 2008) Grosz explores, among others, the interconnections between art and affect. Citing Deleuze, Grosz claims that art 'is of the animal,' and she writes:

Art, according to Deleuze, does not produce concepts, though it does address problems and provocations. It produces sensations, affects, intensities as its mode of addressing problems, which sometimes aligns with and link to concepts, the object of philosophical production, which are how philosophy deals with problems. (Grosz 2008: 10)

Grosz follows Deleuze in his defense of art as affirmative and life-enhancing and like him, she denounces the representational aspects of art. Instead, she emphasizes art as 'the art of affect,' that is, 'a system of dynamized and impacting forces,' with a capacity to produce and generate intensity, 'which directly impacts the nervous system and intensifies sensation' (2008: 12). Art is connected to the forces in nature, which are at work in human and animal bodies, in the earth and in the universe at large.

In a footnote, Grosz clarifies her understanding of affects as opposed to the phenomenological notion of lived experience:

Sensations, affects, intensities, while not readily identifiable, are clearly closely connected with forces, and particularly bodily forces, and their qualitative transformations. What differentiates them from experience, or from any phenomenological framework, is that they link the lived or phenomenological body with cosmological forces, forces of the outside, that the body itself can never experience directly. Affects and intensities attest to the body's immersion and participation in nature, chaos, materiality (2008: 12).

Art as affect or intensities is thus cosmically connected to forces that exceed human beings, individual bodies or human subjectivities. There is something inhuman in art that is produced through human creativity, and it is this affective aspect of art that is of interest to Grosz, as it is to Deleuze and Guattari. Art, through the plane of composition, which it casts, is 'the way that the universe most intensifies life, enervates organs, mobilizes forces (2008: 33). And according to Grosz, what philosophy and art have in common is 'their capacity to enlarge the universe by enabling its potential to be otherwise, to be framed through concepts and affects' $(2008,33)$. These capacities are to her among 'the most forceful ways in which culture generates a small space of chaos within chaos where chaos can be elaborated, felt, thought' (2008: 33). 


\section{CONCLUSION}

In this article, I have tried to account for the way that the question of mood constitutes a central concern, not only in Felski's attack on critique as a genre and ethos, but also that the concept plays a vital part in her proposed 'post-critical' approach, which she launches as an alternative to critique in the practice of interpretation. And, having formulated some critical questions and comments, above all in regards to her appropriation of Heidegger's understanding of Stimmung or attunement, I have, in the second part of this article, introduced another theoretical approach to the concept of mood, thought as affect, as it appears in the philosophy of Deleuze and Guattari. Subsequently, I have shown how this notion of affect has been embraced by both Braidotti and Grosz in their feminist theories. As I have noted, there are marked differences in the way Felski, Braidotti and Grosz approach and use the concept of mood in their respective theorizing, and accordingly, these different approaches generate different methodological and epistemological questions and implications for feminist epistemic habits.

Despite the problems and questions that I have articulated in relation to Felski's denouncement of critique, I remain sympathetic to her theoretical intervention and her advocacy for positive identification in her post-critical approach. I value her effort to create a debate; not only in gender studies, but also in literary studies and cultural studies more broadly. Felski's polemic position forces us to reflect on our moods and methods of interpretive scholarship and the affects that govern our orientations. Her expressed aim is to re-describe and reorient critical and interpretive practices in such a way that interpretation no longer exclusively pursues negative inquiries in the mode of a 'hermeneutics of suspicion.' In her view, the most salient approach to interpretation must also include a 'hermeneutic of trust or restoration.' As such, she not only pays heed to Ricoeur and Sedgwick's demand for greater complexity in the appropriation of mood, method and affect in the interpretive enterprise, but also acknowledges that parts of the critical heritage in critique will and may be restored through her new 'post-critical' approach.

The practice of reading and interpretation remains a major concern in any feminist scholarship, and the methods and affects that inform these practices ought to be continually questioned. For this effort Felski should be thanked, whether or not we support her arguments or question her assumptions and conclusions. However, Felski rarely, if ever, mentions Deleuzian affect theory, nor does she include any references to the host of theorists - non-feminist, feminist and queer theorists alike - who find great inspiration in Deleuze and Guattari's work on affect. Even if she does not agree with them, it would have been of interest to many had she engaged with some of these scholars of affect studies, since they have already made a great impact on literary studies as well as cultural studies at most institutions in the U.S. and Europe.

Neither Braidotti's nor Grosz' approach to the question of mood, using Deleuze and Guattari's notion of affect, can be subsumed under Felski's understanding of critique, performed in the negative mood. Their Deleuzian theorizing represents important theoretical practices within feminist theory today. In addition to these two, suffice it to mention some of the most influential feminist theorists today, who likewise mobilize a Deleuzian framework in their respective works: Tamsin Lorraine (1999), Jasbir Puar (2007) Claire Colebrook (2012), Patricia Ticineto Clough (2010) and Dorothea Olkowski (2014).

Rosi Braidotti, for her part, practices an affirmative approach to feminist theorizing and in so doing, provides important correctives to Felski's somewhat categorical denouncement of critique. Braidotti's nomadic understanding of the subject furnishes new insights into the complexities of agency and the differentiated and affective assemblages and networks into which the feminist subject is implicated in the age of techno-science. Elizabeth Grosz' Deleuzian approach to art as affect introduces yet another radically different approach than Felski's phenomenological approach to the aesthetic experience. Both Braidotti and Grosz' respective Deleuzian takes on mood as affect raises different questions, with important implications for feminist epistemic practices.

For one, it raises the question of whether or not it is sufficient to cast the subject in terms of a phenomenological framework (be it within the mood of soupcon or restoration) when accounting for the complex webs of interconnections and assemblages that the subject are affected by in the age of technology. And we may ask if it is possible, without difficulty, to merge phenomenological methods and concepts with Heidegger's existential hermeneutics and Latour's Actor-Network-Theory?

I would also be curious as to how the theories of Latour and Deleuze could be productively thought together. Even if they are engaged in different projects using different methods, would it not be interesting to explore Deleuze's thinking on affect and the emergence of rhizomic networks in relation to Latour's theories of orientations and actor network? Furthermore, I would be interested in pursuing an exploration of how identification might be thought in terms of affirmative affect in a Nietzschean-Deleuzian sense.

The feminist treatment of mood, method and affect is, needless to say, to be continued. New and unpredictable interventions will undoubtedly occur, hopefully bringing new questions and challenges into the debate, which will affect the epistemic habits in feminist theory - be it affirmatively or negatively - in the time to come. 


\section{REFERENCES}

Beauvoir, S. (1997). The Second Sex. Trans. H.M. Parshley. London: Vintage.

Braidotti, R. (1996). Signs of Wonder and Traces of Doubt: On Terratology and Embodied Differences. In: R. Braidotti and N. Lykke, eds., Between Monsters, Goddesses and Cyborgs (pp. 135-152). London: Zed Books.

Braidotti, R. (2002). Metamorphoses: Towards A Materialist Theory of Becoming. Cambridge: Polity Press.

Braidotti, R. (2006). Affirmation versus Vulnerability: On Contemporary Ethical Debates. Symposium: Canadian Journal of Continental Philosophy, 10(1), pp. 235-254. https:/ / doi.org/10.5840/symposium200610117

Braidotti, R. (2013). The Posthuman. Cambridge: Polity Press.

Butler, J. (1990). Gender Trouble: Feminism and the Subversion of Identity. London: Routledge.

Clough, P.T. (2010). The Affective Turn: Political Economy, Biomedia, and Bodies. In: M. Gregg and G.J. Seighworth, eds., The Affect Theory Reader (pp. 206-228). Durham: Duke University Press.

Colebrook, C. (2012). Blake, Deleurian Aesthetics and the Digital. London: Bloomsbury Academic Press.

Deleuze, G. and Guattari, F. (1987). A Thousand Plateaux: Capitalism and Schirophrenia. Trans. B. Massumi. Minneapolis: University of Minnesota Press.

Deleuze, G. and Guattari, F. (1994). What Is Philosophy? Trans. H. Tomlinson and G. Burchell. New York: Columbia University Press.

Felski. R. (2015). The Limits of Critique. Chicago: Chicago University Press.

Felski. R. (2016). Identification: A Defense. Proceedings of A Critique of Our Own: On the Epistemic Habits of Academic Feminism, University of Turku, April 14-16, 2016.

Grosz, E. (2008). Chaos, Territory, Art: Delenze and the Framing of the Earth. New York: Columbia University Press.

Heidegger, M. (1962). Being and Time. Trans. J. Macquarrie and E. Robinson. New York: Harper and Row.

Heidegger, M. (1975). Early Greek Thinking. Trans. D.F. Krell and F.A. Capuzzi. San Francisco: Harper.

Heidegger, M. (1997). Kant and the Problem of Metaphysics. Trans. R. Taft, 5th edition. Bloomington: Indiana University Press.

Husserl, E. (2006). The Idea of Phenomenology. Trans. W.P. Alston. Dordrecht: Kluwer Academic Publisher.

Klein, M. (1998). Love, Guilt and Reparation. London: Vintage.

Latour, B. (2005). Reassembling the Social: An Introduction to Actor-Network-Theory. Oxford: Oxford University Press.

Lorraine, T. (1999). Irigaray and Deleuze: Experiments in Visceral Philosophy. Ithaca: Cornell University Press.

Moi, T. (2001). What Is a Woman? And Other Essays. Oxford: Oxford University Press.

Olkowski, D. (2014). Birth in Beauty and the Power of Sensation. In: A. Calcagno, J. Vernon and S.G. Lofts, eds., Intensities and Lines of Flight: Deleure and Guattari and the Arts (pp. 97-110). London/New York: Rowman \& Littlefield.

Puar, J. (2007). Terrorist Assemblages: Homonationalism in Queer Times. Durham: Duke University Press.

Ricoeur, P. (1979). Freud and Philosophy: An Essay on Interpretation. Trans. D. Savage. New Haven: Yale University Press.

Sedgwick, E.K. (1997). Paranoid Reading and Reparative Reading. In E.K. Sedgwick, ed., Novel Gazing: Queer Readings in Fiction (pp. 1-40). Durham: Duke University Press.

Sedgwick, E.K. (2003). Touching Feeling: Affect, Pedagogy, Performativity. Durham: Duke University Press.

Smith, M. (1995). Engaging Characters: Fiction, Emotion, and the Cinema. Oxford: Clarendon Press.

Citation: Mortensen, E. (2017). Mood, Method and Affect: Current Shifts in Feminist Theory. Feminist Encounters: A Journal of Critical Studies in Culture and Politics, 1(1), 02. https://doi.org/10.20897/femenc.201702

Copyright (C) 2017 by Author/s and Licensed by Lectito BV, Netherlands. This is an open access article distributed under the Creative Commons Attribution License which permits unrestricted use, distribution, and reproduction in any medium, provided the original work is properly cited. 